\title{
Oak somatic and gametic embryos maturation is affected by charcoal and specific aminoacids mixture
}

\author{
Beatriz Pintos $^{1}$, Jose A. MANZANERA ${ }^{2 *}$, M. Angeles Bueno ${ }^{1}$ \\ ${ }^{1}$ Forest Biotech Lab., INIA-CIFOR, A-6 Km 7,5, 28040 Madrid, Spain \\ ${ }^{2}$ Technical University of Madrid (UPM), ETSI Montes, Ciudad Universitaria, 28040 Madrid, Spain
}

Keywords:

activated charcoal /

amino acids /

cork oak /

gametic embryo /

plantlet acclimation

(Received 4 February 2009; accepted 18 August 2009)

Mots-clés :

charbon actif /

acides aminés /

chêne-liège /

embryon gamétique /

acclimatation de plantule

\begin{abstract}
- Development of both somatic and gametic embryogenesis has many applications in clonal forestry and genetic improvement, for instance as mass-propagation of genetically improved plants and production of pure lines through doubled-haploid plant regeneration from gametic embryos.

- The goal of this work was to improve growth, maturation and plantlet regeneration of cork oak (Quercus suber L.) embryos from both somatic and gametic origin.

- Activated charcoal promoted a significant increase in growth in terms of relative size and weight of both somatic and doubled-haploid embryos, as well as a more efficient control of secondary somatic embryogenesis during development. A significant interaction was also observed with amino acid nutrition. While some amino acids (i.e., glutamine, arginine or asparagine) did not show significant differences with the controls, a mixture of these three amino acids or gamma amino butyric acid stimulated embryo growth. The highest survival rate during acclimation of plantlets from both somatic and doubled-haploid origin was obtained when the embryos had been previously cultured on basal medium with $3 \%$ sucrose and $1 \%$ activated charcoal for two months at $4{ }^{\circ} \mathrm{C}$ and germinated on medium supplemented with 6-benzylaminopurine and indole-3-butyric acid.

- We obtained more than 900 cork oak plantlets acclimated from several embryogenic lines, with a high survival rate, demonstrating that this methodology is applicable for large scale plantlet production. We also report the first regeneration of doubled-haploid plantlets in cork oak.
\end{abstract}

Résumé - La maturation des embryons gamétiques et somatiques de chêne est affectée par le charbon et le mélange d'aminoacides spécifiques.

- Le développement des deux embryogenèses gamétique et somatique a de nombreuses applications dans la foresterie clonale et l'amélioration génétique, par exemple en tant que propagation en masse de plants génétiquement améliorés et la production de lignées pures par régénération de plants haploïdes doublés d'embryons gamétiques.

- L'objectif de ce travail était d'améliorer la croissance, la maturation et la régénération des plantules des embryons de chêne-liège (Quercus suber L.) des deux origines gamétique et somatique.

- Le charbon actif a favorisé une augmentation significative de la croissance en termes de taille et de poids des embryons haploïdes doublés et somatiques, ainsi qu'un contrôle plus efficace de l'embryogenèse somatique secondaire au cours du développement. Une interaction significative a également été observée avec la nutrition aminoacide. Alors que certains acides aminés (c'est-à-dire, la glutamine, l'arginine ou l'asparagine) ne montrent pas de différences significatives avec les témoins, un mélange de ces trois acides aminés ou l'acide butyrique amino gamma a stimulé la croissance de l'embryon. Le taux de survie le plus élevé au cours de l'acclimatation des plantules d'origine à la fois somatique et haploïde doublé, a été obtenu lorsque les embryons ont été auparavant cultivés sur milieu de base à $3 \%$ de saccharose et de $1 \%$ de charbon actif pendant deux mois à $4{ }^{\circ} \mathrm{C}$ et ont germé sur un milieu complété par la 6-benzylaminopurine et l'acide indole-3-butyrique.

- Nous avons obtenu plus de 900 plantules de chênes-lièges acclimatés issus de plusieurs lignes embryogéniques, avec un taux de survie élevé, ce qui démontre que cette méthode est applicable pour la production à grande échelle de plantules. Nous annonçons également la première régénération de plantules haploïdes doublés de chêne-liège.

\footnotetext{
*Corresponding author: joseantonio.manzanera@upm.es
} 


\section{INTRODUCTION}

Cork oak (Quercus suber L.) is a forest species of high ecological value in many Mediterranean countries. In addition, the cork is a raw material of economic value for the wine industry and many other products contributing to the rural development of the areas where this tree is native. Nevertheless, its long life span and irregular seed crops, the difficulty of seed conservation and of vegetative reproduction are serious drawbacks for the use of the classical genetic improvement programs in this species. Somatic embryogenesis has been tested for largescale plant propagation of a range of tree species (Bueno et al., 1992; Hernandez et al., 2003a; Lelu-Walter and Pâques, 2009; Manzanera et al., 1993; Park, 2002; Sutton, 2002). Nevertheless, embryo dormancy and immaturity problems needed to be overcome. Osmoticum (high sucrose concentration) and chilling treatments had been tested in order to promote germination of cork oak somatic embryos (Fernández-Guijarro et al., 1995; García-Martín et al., 2001) and cytokinin application increased apex elongation of germinating cork oak somatic embryos (González-Benito et al., 2002; Hernández et al., 2003b).

A different approach is based on the production of pure lines through doubled-haploid plant regeneration from gametic embryos induced in anther culture (Bueno et al., 1997). In woody angiosperms, gametic embryogenesis has been induced either by anther culture, microspore culture or parthenogenesis in about 80 species, e.g., Malus domestica (Höfer, 2004), Populus spp. (Baldursson et al., 1993; Deutsch et al., 2004), etc. By this approach, the cumbersome method of repeated backcrossings is achieved in one step. Problems of identification of the cellular origin and genotypic composition of anther-derived embryos were overcome through the use of molecular markers, i.e., enzymes and random amplified polymorphic DNA (RAPD; Bueno et al., 2000) and simple sequence repeats (SSR; Gomez et al., 2001), by ploidy level studies through flow cytometry (Bueno et al., 2003; Loureiro et al., 2005), and by cytological analysis of early microspore divisions (Pintos et al., 2005). All these methods corroborated the gametic origin and the genetic variability of the anther embryos from different haploid cells (microspores). Finally, cork oak haploid embryos were treated with antimitotic agents in order to obtain doubled-haploid plantlets (Pintos et al., 2007).

Little attention has been devoted to late maturation and germination. During maturation, cell expansion and storage substance accumulation takes place. The correct storage of reserve substances is crucial for fuelling the germination process (Merkle et al., 1995). Embryo weight increase is an indicator of embryo quality and a pre-requisite for successful germination (García-Martin et al., 2005). Our objective was to develop an efficient method for plantlet regeneration of cork oak (Quercus suber L.) either from somatic or anther-derived haploid embryos.

In the present article, we studied the effect of substances such as activated charcoal and amino acids on the growth of cork oak embryos, and the role of plant growth regulators in the stimulation of germination. The most successful results obtained with somatic embryos were then successfully applied to doubled-haploid embryos from anther origin.

\section{MATERIAL AND METHODS}

\subsection{Plant material}

Branches bearing catkins were collected every week in May, during the flowering period of Quercus suber L., from 10 selected trees, five of them located in Extremadura (Western Spain) and five in Madrid. Immature acorns were collected every two weeks, from the same selected trees, during the period of fruit development, from late July to the beginning of September. Immature acorns and catkins, between 0.5 and $1 \mathrm{~cm}$ in length, were collected and surface-sterilized by immersion in $70 \%(\mathrm{v} / \mathrm{v})$ ethanol for $30 \mathrm{~s}$ and in $2 \%(\mathrm{v} / \mathrm{v})$ sodium hypochlorite (35 $\mathrm{g} \mathrm{L}^{-1}$ active chlorine) with a drop of "Tween 20 " for $20 \mathrm{~min}$ followed by three rinses in sterile distilled water of $10 \mathrm{~min}$ each. Immature zygotic embryos and anthers were isolated, dissected and cultured under aseptic conditions.

\subsection{Culture media}

Basal culture medium for both somatic and anther derived corkoak embryos contained full macronutrients (Sommer et al., 1975, medium 1), microminerals and cofactors (Murashige and Skoog 1962), 3\% (w/v) sucrose and was solidified with $0.8 \%(\mathrm{w} / \mathrm{v})$ agar (Bueno et al., 1992). This basal medium will be designated SM1X throughout the text. Medium containing double concentration of both macronutrients (Sommer et al., 1975) and microminerals and cofactors (Murashige and Skoog, 1962), 15\% (w/v) sucrose and solidified with $0.8 \%$ (w/v) agar, will be designated SM2X throughout the text. All media were adjusted to $\mathrm{pH}=5.6$ after addition of agar and before autoclaving at $1 \mathrm{~atm}\left(120{ }^{\circ} \mathrm{C}\right)$ for $20 \mathrm{~min}$. In all experiments, plant growth regulators and activated charcoal are added to the medium before autoclaving. Amino acids are added to the medium after autoclaving by filter-sterilization $(0.22 \mu)$. Medium was dispensed in $9 \mathrm{~cm}$ diameter sterile Petri dishes ( $25 \mathrm{~mL}$ per dish).

\subsection{Somatic embryo induction from zygotic embryos}

Cork oak immature zygotic embryos were cultured on SM1X medium supplemented with $0.5 \mathrm{mg} \mathrm{L}^{-1}$, 2,4-dichlorophenoxyacetic acid (2,4-D) (induction medium) for one month. Then embryos were transferred to SM1X medium supplemented with $500 \mathrm{mg} \mathrm{L}^{-1}$ glutamine (Gln) without 2,4-D.

\subsection{Haploid embryo induction from anther culture}

Cork oak anthers bearing microspores at the uninucleate stage were pretreated by chilling at $4{ }^{\circ} \mathrm{C}$ for a maximum of $7 \mathrm{~d}$ and then were cultured on SM1X supplemented with $1 \%(\mathrm{w} / \mathrm{v})$ activated charcoal. Anther cultures were subjected to a heat shock treatment at $33^{\circ} \mathrm{C}$ for $5 \mathrm{~d}$ in the dark (Bueno et al., 1997). One month later, haploid embryogenic masses emerged from inside the anthers and were subjected to antimitotic treatments.

\subsection{Doubled-haploids obtained by antimitotic treatments}

Oryzalin (Duchefa ${ }^{\circledR}$ ) $10 \mu \mathrm{M}$ in 10\% di-methyl-sulfoxide (DMSO) or amiprophos methyl (Fluka ${ }^{\circledR}$ ) $10 \mu \mathrm{M}$ in $30 \%$ acetone were used in 
vitro to induce chromosome doubling. All the solutions were sterilized by ultrafiltration $(0.22 \mu)$. Haploid embryogenic masses emerging from inside the anthers and containing initial translucent globular embryos were immersed into these antimitotic solutions for $48 \mathrm{~h}$ in the dark at $24 \pm 1{ }^{\circ} \mathrm{C}$. Then, they were subcultured on SM1X medium supplemented with $500 \mathrm{mg} \mathrm{L}^{-1} \mathrm{Gln}$. Doubled-haploid induction rate was evaluated two months later (Pintos et al., 2007).

\subsection{Effect of amino acids and activated charcoal on embryo growth}

Immature translucent embryos at the cotyledonar stage, about $3-$ $4 \mathrm{~mm}$ in size and approximate fresh weight of about $30 \mathrm{mg}$, either from somatic origin or from anther-derived doubled-haploids were cultured in $9 \mathrm{~cm}$ diameter Petri dishes containing $25 \mathrm{~mL}$ SM1X medium (control) or supplemented with different amino acids: Gln, arginine (Arg), asparagine (Asn), gamma-amino butyric acid (GABA) or a mixture of the three amino acids Gln, Arg and Asn (3.5 mM each). In the case of somatic embryos, all amino acid treatments were either combined with or without $1 \%$ activated charcoal. Doubled-haploid embryos from six different parent trees were subjected to the same amino acid treatments and the control, but only in combination with $1 \%$ activated charcoal. Then, both cultures (i.e. from somatic or anther-derived origins) were subjected to a temperature of $25 \pm 1{ }^{\circ} \mathrm{C}$ in darkness.

For automated sizing of embryos, the projected area of each embryo was measured with an image analyzer (Image Tool ${ }^{\circledR}$ ). Prior to their establishment in the different amino acid and activated charcoal treatments, each embryo was weighed in aseptic conditions and sized using an automated procedure to capture the projected area of each embryo (Image Tool ${ }^{\circledR}$ ). One month later, both parameters were measured and correlations fitted with the statistical package SPSS 10.0. (SPSS, 1999). Embryo maturation was assessed by two indices, the relative increment in projected area $(R A I)$, and the relative weight increment $(R W I)$ :

$$
R A I=\left(A_{\mathrm{f}}-A_{\mathrm{i}}\right) / A_{\mathrm{i}}
$$

where $A_{\mathrm{i}}$ is the embryo initial projected area and $A_{\mathrm{f}}$ is the final projected area.

$$
R W I=\left(W_{\mathrm{f}}-W_{\mathrm{i}}\right) / W_{\mathrm{i}},
$$

where $W_{\mathrm{i}}$ is the initial weight and $W_{\mathrm{f}}$ is the final weight.

For this experiment, 20 somatic embryos were cultured in each of the 12 treatments (the control and five amino acid treatments, with or without activated charcoal). The different embryo lines were homogeneously distributed among treatments. The experiment was repeated three times, thus a total of 720 embryos was used. In the case of doubled-haploids, also 20 embryos were cultured in each of the control and five amino acid treatments, and the experiment was repeated three times, thus a total of 360 embryos were used.

\subsection{Effect of the combination of different plant growth regulators on the germination of somatic and doubled-haploid embryos}

Cork oak embryos either from somatic or doubled-haploid origin, were cultured on SM1X medium supplemented with $1 \%$ activated charcoal for one month. When they reached approximately 1.5 to $2 \mathrm{~cm}$ in length and $700-1000 \mathrm{mg}$ fresh weight, they were transferred to SM2X medium supplemented with $1 \%$ activated charcoal and stored at $4{ }^{\circ} \mathrm{C}$ in darkness for two months stratification. Then they were imbibed in sterile distilled water, inside $10 \mathrm{~mL}$ tubes for $24 \mathrm{~h}$ at $4{ }^{\circ} \mathrm{C}$ in darkness.

Germination of somatic embryos was induced in SM1X medium supplemented with different combinations of 6-benzylaminopurine (BAP; 0.05, 0.1, 0.25 and $0.5 \mathrm{mg} \mathrm{L}^{-1}$ ) with indole-3-butyric acid (IBA, $0.1 \mathrm{mg} \mathrm{L}^{-1}$ ), naphthaleneacetic acid (NAA, $0.1 \mathrm{mg} \mathrm{L}^{-1}$ ), or gibberellic acid $\left(\mathrm{GA}_{3}, 0.1 \mathrm{mg} \mathrm{\textrm {L } ^ { - 1 }}\right)$ and a control treatment without plant growth regulators. The treatments to induce germination of doubled-haploid embryos were combinations of BAP $(0.05,0.1$, $\left.0.25 \mathrm{mg} \mathrm{L}^{-1}\right)$ with IBA $\left(0.1,1 \mathrm{mg} \mathrm{L}^{-1}\right)$ and a control treatment without plant growth regulators. In both somatic and doubled-haploid embryos, 50 individuals were cultured per treatment under a 16-h photoperiod $\left(100 \mu \mathrm{mol} \mathrm{m} \mathrm{m}^{-2} \mathrm{~s}^{-1}\right)$ and $25 \pm 1{ }^{\circ} \mathrm{C}$ temperature, and the experiment was repeated three times.

\subsection{Effect of the concentration of the stratification medium on the germination of somatic and doubled-haploid embryos}

Cork oak embryos either from somatic or doubled-haploid origin were matured on SM1X medium supplemented with $1 \%$ activated charcoal for one month. When they reached approximately 1.5 to $2 \mathrm{~cm}$ in length and 700-1000 $\mathrm{mg}$ fresh weight, they were transferred to two different stratification media: either SMIX or SM2X medium supplemented with $1 \%$ activated charcoal and stored at $4{ }^{\circ} \mathrm{C}$ in darkness for two months. Then they were imbibed in sterile distilled water, inside $10 \mathrm{~mL}$ tubes for $24 \mathrm{~h}$ at $4{ }^{\circ} \mathrm{C}$ in darkness.

Germination of somatic embryos was induced in SM1X medium with the sucrose concentration decreased to $1.5 \%(\mathrm{w} / \mathrm{v})$, the agar concentration increased to $1 \%(\mathrm{w} / \mathrm{v})$, and supplemented with $0.05 \mathrm{mg} \mathrm{L}^{-1}$ BAP and $0.1 \mathrm{mg} \mathrm{L}^{-1}$ IBA, under a 16-h photoperiod $\left(100 \mu \mathrm{mol} \mathrm{m} \mathrm{m}^{-2} \mathrm{~s}^{-1}\right)$ and $25 \pm 1^{\circ} \mathrm{C}$ temperature.

For the experiment with somatic embryos, a total of 5299 somatic embryos were cultured on SM2X medium and 2038 somatic embryos were cultured on SM1X medium. In the case of doubled-haploid embryos, two hundred embryos were cultured per treatment and the experiment was repeated three times.

\subsection{Acclimation of cork oak plantlets}

Plantlets produced during the two previous germination experiments were extracted from the germination test tubes taking care not to damage the roots. Agar was washed with tap water and the plantlets were transferred to $100 \mathrm{~mL}$ nursery pots filled with peat: perlite: vermiculite (1:1:1). Then they were subjected to a preventive treatment with PREVICUR ${ }^{\circledR}$ fungicide (Propamocarb $1.8 \mathrm{~g} \mathrm{~L}^{-1}$ ). The relative humidity of the acclimation room was close to $100 \%$ using a fog system. Photoperiod was set to $16 \mathrm{~h}$ light $\left(100 \mu \mathrm{mol} \mathrm{m} \mathrm{m}^{-2} \mathrm{~s}^{-1}\right)$ and $8 \mathrm{~h}$ darkness and temperature to $25 \pm 1{ }^{\circ} \mathrm{C}$. There was a gradual reduction in relative humidity during the next days. After two or three weeks, the plantlets were transferred to the greenhouse. In the second year of nursery, the plantlets were transferred to $2-\mathrm{L}$ pots with peat: vermiculite (3:1). The survival rate was calculated as the ratio between the number of survived plantlets one year after transfer to the 2-L pots and the total amount of plantlets produced in the laboratory and transferred to $100 \mathrm{~mL}$ nursery pots. 


\subsection{Statistics}

The effects of activated charcoal and amino acids on embryo growth were compared by analysis of variance (General Linear Model of the SPSS 10.0. statistical package; SPSS, 1999). Means were compared with Duncan's multiple range test at the 5\% significance level. For statistical calculations of the germination (i.e., elongation of both embryo root and shoot), survival and acclimation rates of the different experiments, expressed as percentages, a log-linear model was fitted using a Chi-square test. Asymptotic standard errors of the parameter estimates were computed by the Delta method (Lee, 1977). The ratio of the log-linear parameter estimate to its standard error was used to obtain the frequency significance level.

\section{RESULTS}

\subsection{Effect of amino acids and activated charcoal on somatic embryo growth}

Forty one somatic embryo lines were obtained from the ten selected trees. The results obtained in relative size increase are shown in Figure 1A. Significant differences in growth were due to the presence of activated charcoal in the culture medium. Relative growth in projected area of the embryos cultured in activated charcoal without amino acids averaged $871 \%$ per month. In contrast, the growth of embryos subjected to the control treatment (no amino acids and no activated charcoal) was only $167 \%$ per month. The addition of a mixture of three amino acids (Gln, Arg and Asn) or GABA produced a significant increase of embryo size as compared to the control without activated charcoal. For instance, the combination of the three amino acids without activated charcoal promoted a 570\% increment per month, while when this treatment was combined with the presence of activated charcoal, growth increased to $733 \%$ per month.

Similar results were obtained for fresh weight relative growth (Fig. 1B). Growth in weight was significantly higher in embryos cultured on medium containing activated charcoal (1736\% per month), where embryos reached a size of $1.3 \mathrm{~cm}$ in length and an approximate fresh weight of $0.7 \mathrm{~g}$ (Fig. 2, A1 and A2), than in the control (505\% per month), where final fresh weight was about $250 \mathrm{mg}$ (Fig. 2, B1 and B2). Also, in the treatment with a mixture of three amino acids (Gln, Arg and Asp) without activated charcoal, the fresh weight increment (1598\% per month) was significantly higher than the control. GABA, Gln and Asn treatments also induced significantly higher $R W I$ than the control (Fig. 1B).

Amino acids promoted embryo growth in the absence of activated charcoal but none of the amino acid treatments improved embryo growth over the no-amino acid control in the presence of activated charcoal (Fig. 1B). Furthermore, we observed that in the presence of activated charcoal and without amino acids, cork oak somatic embryos did not show repetitive embryogenesis, while in the absence of activated charcoal, repetitive embryogenesis appeared at the base of many embryos (data not shown).
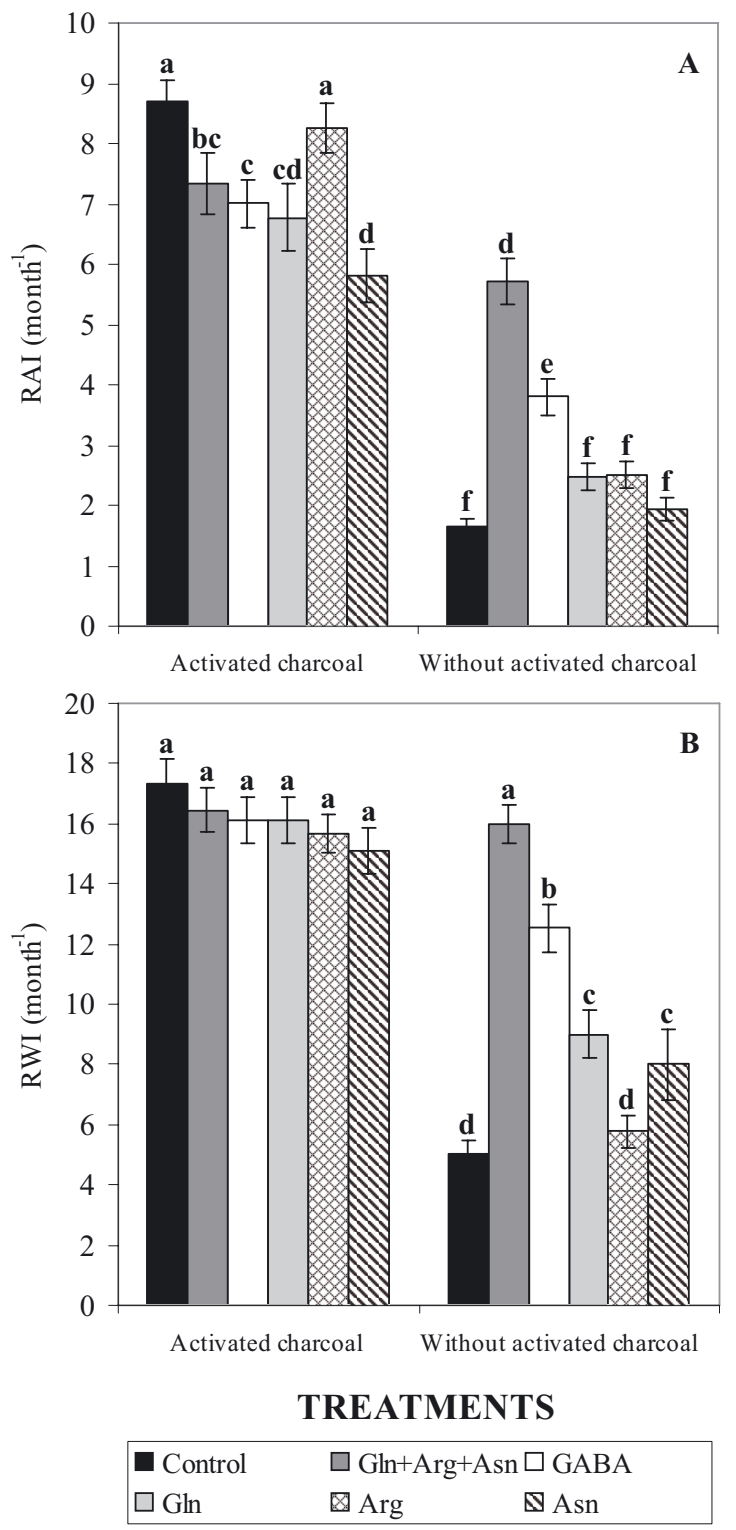

Figure 1. Effect of amino acids glutamine (Gln), arginine (Arg), asparagine (Asn), $\gamma$-amino-butyric acid (GABA), $3.5 \mathrm{mM}$ each, a mixture of the three amino acids Gln, Arg and Asn (3.5 mM each) and the control with or without $1 \%$ activated charcoal on cork oak somatic embryo growth per month. (A) Relative size increment in projected area per month $\left(R A I\right.$, month $\left.^{-1}\right)$. (B) Relative fresh weight increment per month $\left(R W I\right.$, month $\left.^{-1}\right)$. Treatments with different letters are statistically significant at the $5 \%$ level.

\subsection{Effect of amino acids on doubled-haploid embryo growth}

Results on the relative projected area increment are shown in Figure 3A. No significant differences were found among treatments. In general, doubled-haploid embryo growth is slightly lower than that of somatic embryos. For instance, the control medium and that of Arg induced 734 and $723 \%$ 


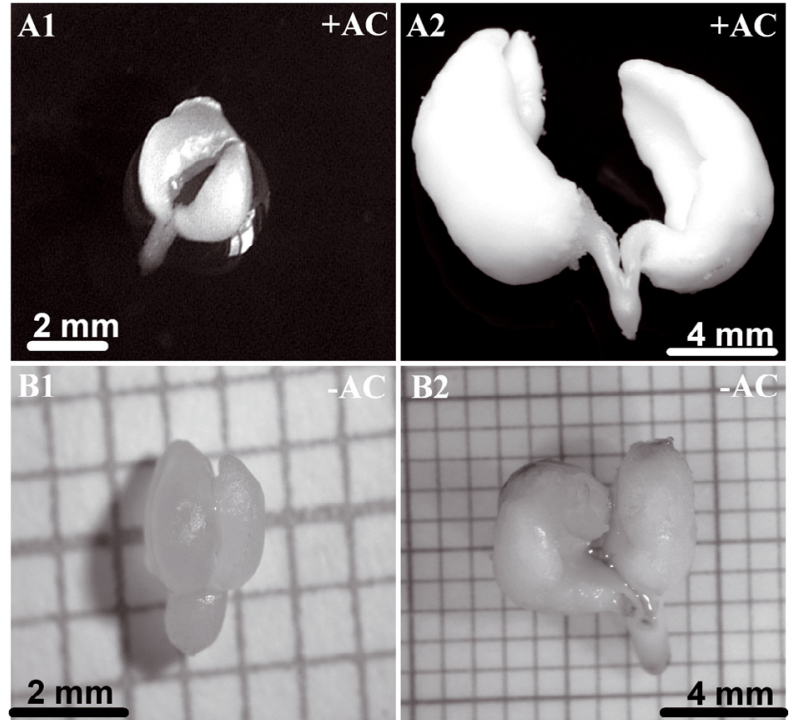

Figure 2. Growth of cork oak somatic embryos. (A1) Initial size of a somatic embryo cultured on medium with activated charcoal (+AC), one month after embryogenesis induction. (A2) Final aspect of a somatic embryo cultured for one month on medium with activated charcoal (+AC). (B1) Initial size of a somatic embryo cultured on medium without activated charcoal $(-\mathrm{AC})$, one month after embryogenesis induction. (B2) Final aspect of a somatic embryo cultured for one month on medium without activated charcoal $(-\mathrm{AC})$.

per month, respectively, in doubled-haploid embryos, while in somatic embryos, $R A I$ raised to 871 and $826 \%$ in the same treatments, respectively (Fig. 1A).

Again, fresh weight relative increment was not significant among treatments (Fig. 3B). In this case, media supplemented either with Gln or Arg or the control showed a similar fresh weight increment, i.e., 1424, 1472 and $1450 \%$ per month, respectively. Values are slightly less than in the case of somatic embryos (about 1600\%, Fig. 1B).

\subsection{Effect of the combination of different plant growth regulators on the germination of somatic and doubled-haploid embryos}

The treatment with BAP (between 0.25 and $0.05 \mathrm{mg} \mathrm{L}^{-1}$ ) and IBA $\left(0.1 \mathrm{mg} \mathrm{L}^{-1}\right)$ induced a significantly higher germination rate (from 38.3 to $43.3 \%$ ) than those of BAP + NAA (25$32 \%$ ) or the control without PGRs (Fig. 4). The combination of $0.1 \mathrm{mg} \mathrm{L}^{-1} \mathrm{GA}_{3}$ with BAP caused a $70 \%$ embryo necrosis and was excluded from the analysis. The higher BAP concentration $\left(0.5 \mathrm{mg} \mathrm{L}^{-1}\right)$ combined with IBA reduced root growth and stimulated shoot proliferation. Doubled-haploid embryos treated with $0.05 \mathrm{mg} \mathrm{L}^{-1} \mathrm{BAP}$ and $0.1 \mathrm{mg} \mathrm{L}^{-1}$ IBA germinated at a significantly higher rate, $18.7 \%$, than the other treatments (Tab. I).
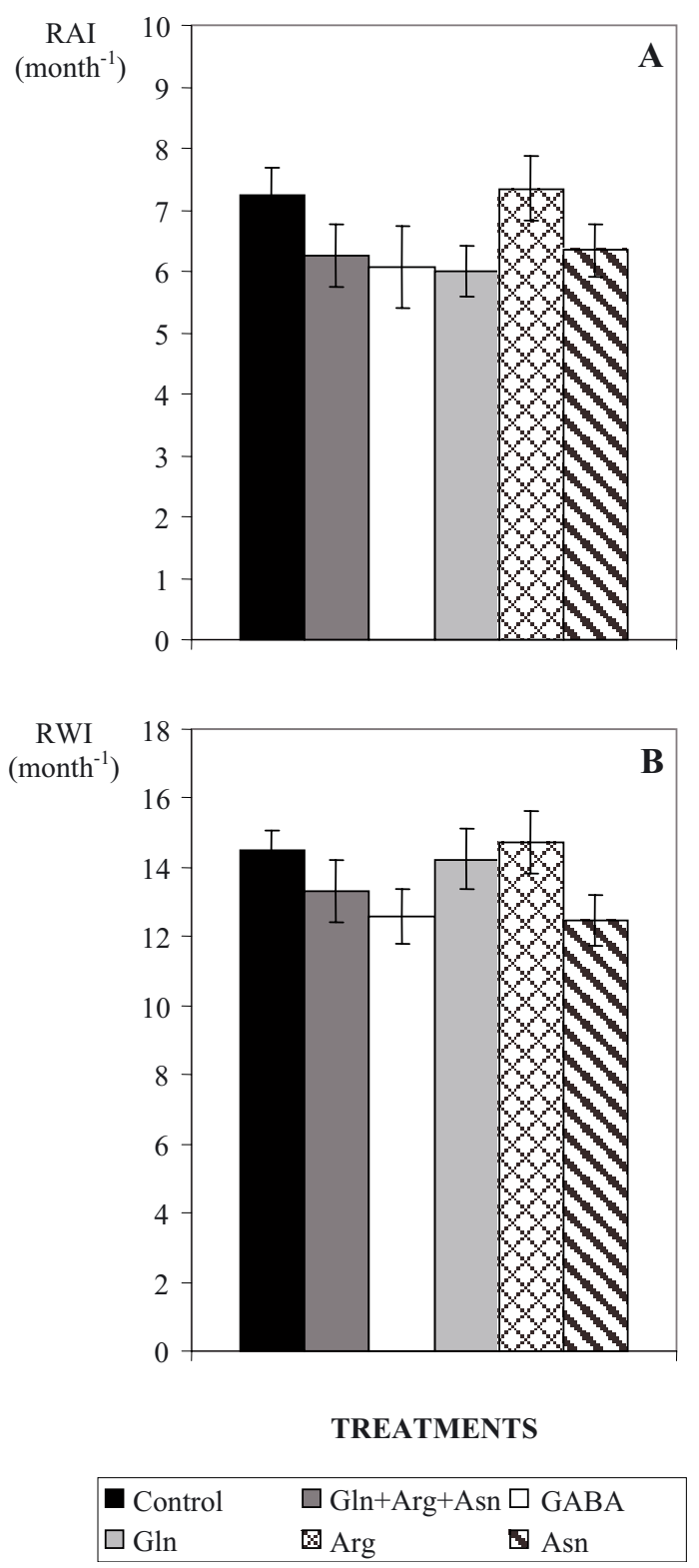

Figure 3. Effect of amino acids glutamine (Gln), arginine (Arg), asparagine (Asn) and $\gamma$-amino-butyric acid (GABA), $3.5 \mathrm{mM}$ each, and the control with $1 \%$ activated charcoal on cork oak gametic embryo growth per month. (A) RAI: relative size increment in projected area per month $\left(\right.$ month $\left.^{-1}\right)$. (B) $R W I$ : relative fresh weight increment per month $\left(\right.$ month $\left.^{-1}\right)$.

\subsection{Effect of the concentration of the stratification medium on the germination of somatic and doubled-haploid embryos}

Somatic embryos stratified on SM1X medium supplemented with $1 \%$ activated charcoal and stored at $4{ }^{\circ} \mathrm{C}$ in darkness for two months showed the highest germination rate (57.2\%) in comparison with those stratified on SM2X medium supplemented with $1 \%$ activated charcoal (Fig. 5). In the case 


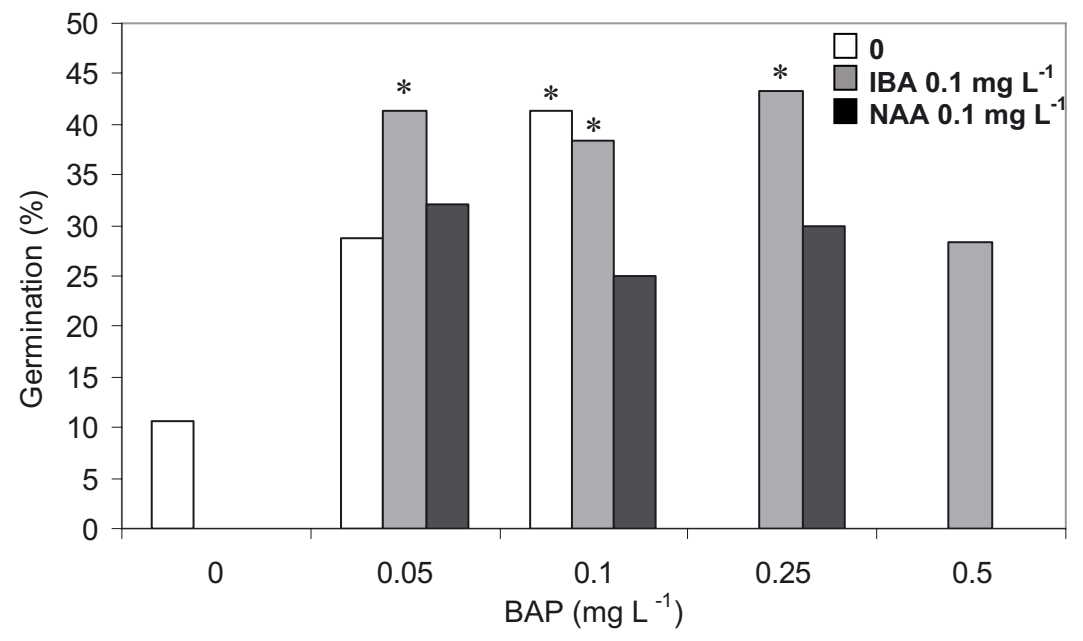

Figure 4. Germination rate (\%) of cork oak somatic embryos treated with 6-benzyl-aminopurine (BAP, $0,0.05,0.1,0.25$ and 0.5 mg $\mathrm{L}^{-1}$ ) combined with IBA $\left(0.1 \mathrm{mg} \mathrm{L}^{-1}\right)$, NAA $\left(0.1 \mathrm{mg} \mathrm{L}^{-1}\right)$ or without auxin (control). Treatments marked with an asterisk (*) were statistically significant at the $5 \%$ level.

Table I. Germination rate (\%) of cork oak doubled-haploid embryos treated with 6-benzyl-adenine (BAP, 0, 0.05, 0.1 and $0.25 \mathrm{mg} \mathrm{L}^{-1}$ ) combined with IBA $\left(0.1,1 \mathrm{mg} \mathrm{L}^{-1}\right)$ or without auxin (control). Treatments marked with an asterisk (*) were statistically significant at the 0.05 level.

\begin{tabular}{lc}
\hline Treatment & Germination (\%) \\
\hline $0.25 \mathrm{mg} \mathrm{L}^{-1} \mathrm{BAP}+0.1 \mathrm{mg} \mathrm{L}^{-1} \mathrm{IBA}$ & 16.7 \\
$0.1 \mathrm{mg} \mathrm{L}^{-1} \mathrm{BAP}+0.1 \mathrm{mg} \mathrm{L}^{-1} \mathrm{IBA}$ & 15 \\
$0.05 \mathrm{mg} \mathrm{L}^{-1} \mathrm{BAP}+0.1 \mathrm{mg} \mathrm{L}^{-1} \mathrm{IBA}$ & $18.7 *$ \\
$0.1 \mathrm{mg} \mathrm{L}^{-1} \mathrm{BAP}+1 \mathrm{mg} \mathrm{L}^{-1} \mathrm{IBA}$ & 9.7 \\
$0.1 \mathrm{mg} \mathrm{L}^{-1} \mathrm{BAP}$ & 11 \\
Control (no PGRs) & 6.3 \\
\hline
\end{tabular}

of doubled-haploid embryos, the germination rate was very low (16.8-17.2\%) and no significant differences were observed between both medium concentrations.

\subsection{Acclimation of cork oak plantlets}

The survival rate of acclimated plantlets from both somatic and doubled-haploid embryos which were stratified on SM1X medium with $1 \%$ activated charcoal for two months at $4{ }^{\circ} \mathrm{C}$ was significantly higher than the survival rate of plantlets coming from embryos stratified on SM2X medium (Fig. 6). Differences also were observed between the survival rate of plantlets from somatic and doubled-haploid origin, which were $77.96 \%$ and $13.96 \%$ respectively in the best stratification treatment (SM1X medium). A total of 909 acclimated plantlets from somatic embryos and 14 from doubled-haploid embryos (Fig. 7), previously cultured in SM1X supplemented with $1 \%$ activated charcoal for one month at $25^{\circ} \mathrm{C}$ and stratified for two months at $4{ }^{\circ} \mathrm{C}$, were obtained. When the SM2X medium was used

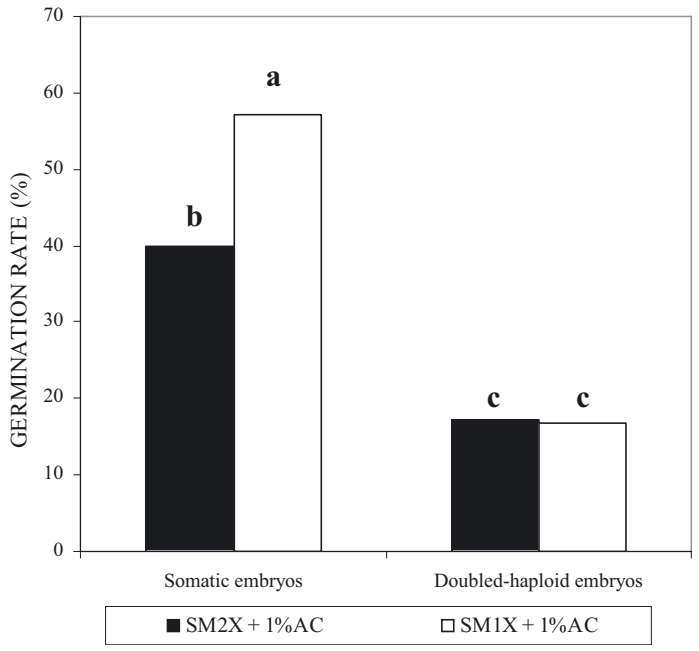

Figure 5. Germination rate (\%) of cork oak somatic and doubledhaploid embryos previously cultured on a stratification medium: $\mathrm{SM} 2 \mathrm{X}+1 \%$ activated charcoal $(\mathrm{AC})$; SM1X $+1 \%$ activated charcoal (AC). Treatments with different letters are statistically significant at the $5 \%$ level.

during stratification, 685 plantlets from somatic and five from doubled-haploid embryos were obtained.

\section{DISCUSSION}

\subsection{Effect of amino acids and activated charcoal on embryo growth}

Embryo growth is a critical step for the development in vitro and germination of somatic embryos (Lelu and Label, 1994; Mauri and Manzanera, 2003). During maturation, cell 


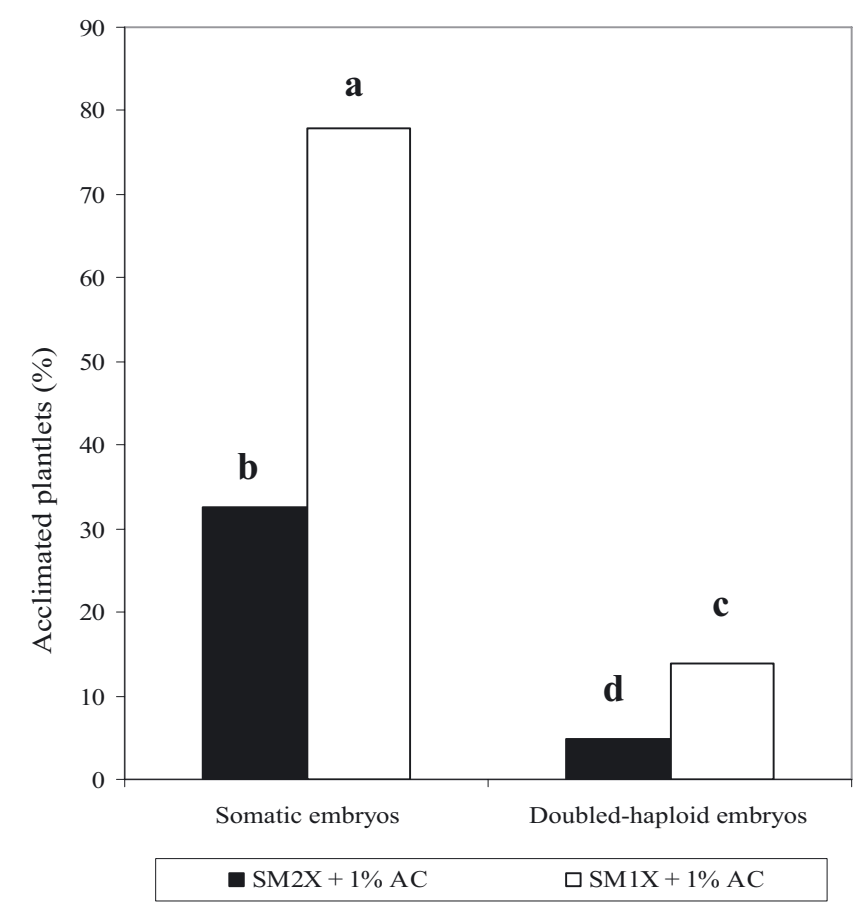

Figure 6. Acclimation rate (\%) of cork oak plantlets from either somatic or doubled-haploid embryos previously cultured on a stratification medium: SM2X $+1 \%$ activated charcoal (AC); SM1X $+1 \%$ activated charcoal (AC). Treatments with different letters are statistically significant at the $5 \%$ level.

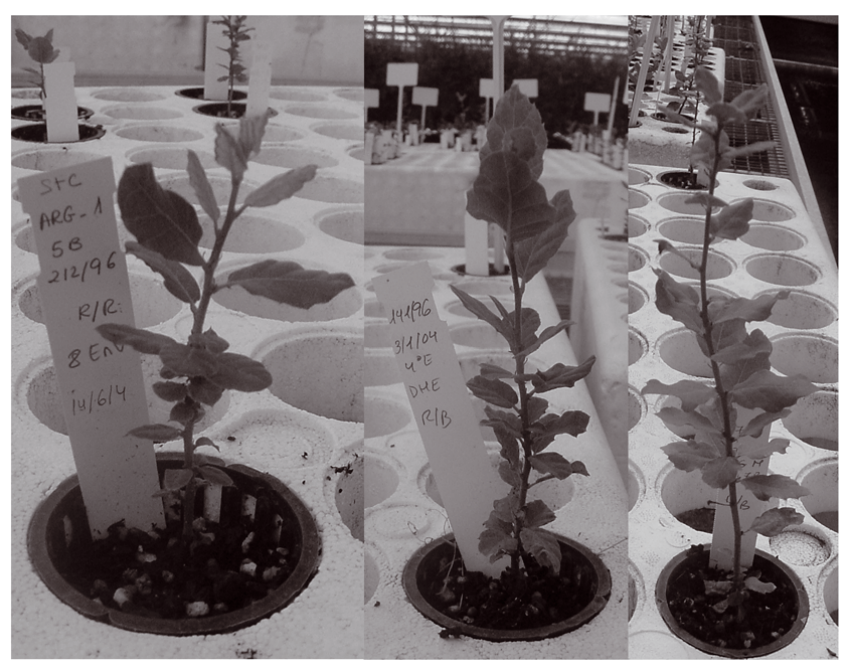

Figure 7. Doubled-haploid plantlets acclimated in the greenhouse.

expansion and accumulation of reserves take place (Merkle et al., 1995), which implies both size and weight increment. In cork oak, this has been significantly promoted by the effect of activated charcoal added to the culture medium. Nevertheless, in some cases growth inhibition has also been reported (Fridborg and Eriksson, 1975; Fridborg et al., 1978), also with embryos from anther origin (Johansson, 1983). The positive effect of $1 \%$ activated charcoal on stopping secondary somatic embryogenesis and promoting somatic embryo growth and later germination has been observed in other woody species, such as Taxus brevifolia (Chee, 1996) and Larix $\times$ marschlinsii (Von Aderkas et al., 2002). Groll et al. (2002) also showed the beneficial effect of $0.5 \%$ activated charcoal on Manihot esculenta somatic embryos. Our results obtained with the growth of cork oak somatic embryos were applied to doubled-haploid embryos from anther origin. The positive effect of activated charcoal on relative growth was assumed and the doubledhaploid embryos were subjected to the amino acid treatments, maintaining the presence of $1 \%$ activated charcoal in the culture medium.

In vitro explants exude inhibitory phenolic compounds to the culture medium that may be adsorbed by activated charcoal (Fridborg et al., 1978), and its darkening effect may attenuate the activity of phenol oxidising enzymes (Linington, 1991). Also, activated charcoal absorbs 5-hydroxi-methyl-2furaldehide (HMF), a secondary product of sucrose autoclaving which reduces plant growth (Rao and Pattabiraman, 1990). Weatherhead et al. (1978) demonstrated that $0.3 \%$ activated charcoal absorbs HMF and stimulates explant growth and induces a 200 to $300 \%$ increment in plantlet number. Another hypothesis for the beneficial effect of activated charcoal is the absorption of auxins liberated by the embryos to the medium during their development, which may interfere with embryo morphology and germination (Merkle et al., 1995). In Quercus suber L., we observed a significant increase of both embryo size and fresh weight due to activated charcoal, as well as a better control of repetitive embryogenesis in mature embryos. This phenomenon, called autoembryony, is frequent in species such as cork oak, and is undesirable during maturation and later stages. This problem has been detected in related Quercus species (Chalupa, 1990). The addition of abscisic acid (ABA) to the maturation medium partially solves that problem, like in $Q$. ilex L. (Mauri and Manzanera, 2004) and in $Q$. suber L. (García-Martin et al., 2005). Amino acids promoted a significant fresh weight increment, except for Arg. In agreement with this results, Lelu-Walter and Pâques (2009) used $1.45 \mathrm{~g} \mathrm{~L}^{-1}$ Gln for hybrid larch somatic embryogenesis, and Gleeson et al. (2004) found that proline stimulated growth of embryogenic cultures of larch (Larix leptoeuropaea Dengler), sitka spruce (Picea sitchensis (Bong.) Carr.) and oak (Quercus robur L.) in stress conditions. Furthermore, the combination of amino acids and activated charcoal gave the best results, similarly to those obtained in Cucumis sativus L. with Gln, Arg, Asn, glycine and cisteine $1 \mathrm{mM}$ together (Ashok and Murthy, 2004).

\subsection{Germination of somatic and doubled-haploid embryos}

We have observed in our experiments that the cork oak somatic embryos previously stratified in medium with higher mineral nutrients and sucrose concentrations (SM2X) germinated at a lower rate than those previously stratified in medium with the lower sucrose concentration (SM1X). Both somatic and doubled-haploid embryos previously cultured in the lower 
concentration medium (SM1X) were more successful in the acclimation phase than those embryos coming from the SM2X medium.

Our results have shown that cytokinin combined with auxins improved a coordinated germination in cork oak, confirming previous research (González-Benito et al., 2002). Germanà and Chiancone (2003) used $1 \mathrm{mg} \mathrm{L}^{-1} \mathrm{GA}_{3}$ and $0.01 \mathrm{mg} \mathrm{L}^{-1}$ NAA for Citrus clementina Hort., obtaining $96 \%$ germination. Baldursson et al. (1993) obtained adventitious shoots from anther embryos of Populus trichocarpa with $2.5 \mu \mathrm{M}$ BAP and $0.005 \mu \mathrm{M}$ NAA and rooted them with $0.25 \mu \mathrm{M}$ IBA. In contrast, Deutsch et al. (2004) germinated embryos obtained from isolated microspores of Populus nigra previously cultured on medium with $1 \mathrm{mg} \mathrm{L}^{-1} \mathrm{BAP}$ and $0.02 \mathrm{mg} \mathrm{L}^{-1}$ NAA.

\subsection{Acclimation of cork oak plantlets}

There are few reports on the effective acclimation of plantlets from somatic or gametic embryogenesis in the genus Quercus. Gingas and Lineberger (1989) only acclimated three plantlets of $Q$. rubra, which died six months later. Ishii et al. (1999) transferred 10 plantlets from somatic embryos of $Q$. serrata, eight of which survived. Chalupa (1990) obtained $78 \%$ survival from 70 Q. robur and 62 from Q. petraea plantlets. Kim et al. (1997) produced 33 plantlets of $Q$. acutissima, 20 of which were transplanted into pots, 12 survived in the greenhouse and eight in the field. Hernández et al. (2003b) transferred to ex vitro conditions a total of 703 plantlets of $Q$. suber from leaf explants, but six months later only 33 survived in the field.

Deutsch et al. (2004) obtained plantlet regeneration percentages lower than $1.2 \%$ in Populus nigra microspore cultures. Germanà and Chiancone (2003) established 54 doubledhaploid plantlets of Citrus clementina Hort. from anther cultures. Our results of 909 cork oak plantlets acclimated from multiple-line somatic embryogenesis, with a high survival rate, show that this methodology is applicable for large scale plantlet production. Nevertheless, doubled-haploid plantlet regeneration is still a challenging task, possibly because the genetic load that is expressed in the doubled-haploid material make them weaker than heterozygous plantlets from somatic origin.

Acknowledgements: This work was supported by project RTA2005- 00118-C02-02. Dr Pintos was recipient of a PhD grant of the National Institute of Agronomic Research (INIA).

\section{REFERENCES}

Ashok K.H.G. and Murthy H.N., 2004. Effects of sugars and amino acids on androgenesis of Cucumis sativus L. Plant Cell Tissue Organ Cult. 78, 201-208

Baldursson S., Nørgaard J.V., Krogstrup P., and Andersen S.B., 1993. Microspore embryogenesis in anther culture of three species of Populus, and regeneration of dihaploid plants of Populus trichocarpa. Can. J. For. Res. 23: 1812-1825.
Bueno M.A., Astorga. R., and Manzanera J.A., 1992. Plant regeneration through somatic embryogenesis in Quercus suber. Physiol. Plant. 85: 30-34.

Bueno M.A., Gómez A., Boscaiu M., Manzanera J.A., and Vicente O., 1997. Stress induced formation of haploid plants trough anther culture in cork-oak (Quercus suber L.). Physiol. Plant. 99: 335-341.

Bueno M.A., Agundez M.D., Gómez A., Carrascosa M.J., and Manzanera J.A., 2000. Haploid origin of cork oak anther embryos detected by enzyme and RAPD gene markers. Int. J. Plant Sci. 161: 363-367.

Bueno M.A., Gómez A., Sepúlveda F., Segui J.M., Testillano, P.S., Manzanera. J.A., and Risueño M.C., 2003. Microspore-derived embryos from Quercus suber anthers mimic zygotic embryos and maintain haploidy in long-term anther culture. J. Plant Physiol. 160: 953960.

Chalupa A.V., 1990. Plant regeneration by somatic embryogenesis from cultured immature embryos of oak (Quercus robur L.) and linden (Tillia cordata Mill.). Plant Cell Rep. 9: 398-401.

Chee P., 1996. Plant regeneration from somatic embryos of Taxus brevifolia. Plant Cell Rep. 16: 184-187.

Deutsch F., Kumlehn J., Ziegenhagen B., and Fladung M., 2004. Stable haploid poplar callus lines from immature pollen culture. Physiol. Plant. 120: 613-622.

Fernández-Guijarro B., Celestino C., and Toribio M., 1995. Influence of external factors on secondary embryogenesis and germination in somatic embryos from leaves of Quercus suber L. Plant Cell Tissue Organ Cult. 41: 99-106.

Fridborg G. and Eriksson T., 1975. Effects of activated charcoal on growth and morphogenesis in cell cultures. Physiol. Plant. 34: 306308.

Fridborg G., Pedersen L., Landstrom E., and Eriksson T., 1978. The effect of activated charcoal on tissue cultures: adsorption of metabolites inhibiting morphogenesis. Physiol. Plant. 43: 104-106.

García-Martin G., González-Benito M.E., and Manzanera J.A., 2001. Quercus suber L. somatic embryo germination and plant conversion: pretreatments and germination conditions. In Vitro Cell. Dev. Biol. Plant 37: 190-198.

García-Martin G., González-Benito M.E., and Manzanera J.A., 2005. Effect of exogenous ABA on embryo maturation and quantification of endogenous levels of ABA and IAA in Quercus suber somatic embryos. Plant Cell Tissue Organ Cult. 80: 171-177.

Germanà M.A. and Chiancone B., 2003. Improvement of Citrus clementina Hort. Ex Tn. microspore-derived embryoid induction and regeneration. Plant Cell Rep. 22: 181-187.

Gingas V.M. and Lineberger R.D., 1989. Asexual embryogenesis and plant regeneration in Quercus. Plant Cell Tissue Organ Cult. 17: 191203.

Gleeson D., Lelu-Walter M.A., and Parkinson M., 2004. Influence of exogenous L-proline on embryogenic cultures of larch (Larix leptoeuropaea Dengler), sitka spruce (Picea sitchensis (Bong.) Carr.) and oak (Quercus robur L.) subjected to cold and salt stress. Ann. For. Sci. 61: $125-128$.

Gómez A., Pintos B., Aguiriano E., Manzanera J.A., and Bueno M.A., 2001. SSR markers for Quercus suber tree identification and embryo analysis. J. Hered. 92: 292-295.

González-Benito M.E., García-Martín G., and Manzanera J.A., 2002. Shoot development in Quercus suber L. somatic embryos. In Vitro Cell. Dev. Biol. Plant 38: 477-480.

Groll J., Gray V.M., and Mycock D.J., 2002. Development of Cassava (Manihot esculenta Crantz.) somatic embryos during culture with abscisic acid and activated charcoal. J. Plant Physiol. 159: 437-443.

Hernández I., Celestino C., and Toribio M., 2003a. Vegetative propagation of Quercus suber L. by somatic embryogenesis. I. Factors affecting the induction in leaves from mature cork oak trees. Plant Cell Rep. 21: 759-764. 
Hernández I., Celestino C., Alegre J., and Toribio M., 2003b. Vegetative propagation of Quercus suber L. by somatic embryogenesis. II. Plant regeneration from selected cork oak trees. Plant Cell Rep. 21: 765770 .

Höfer M., 2004. In vitro androgenesis in apple-improvement of the induction phase. Plant Cell Rep. 22: 365-370.

Ishii K., Thakur R., and Jain S.M., 1999. Somatic embryogenesis and evaluation of variability in somatic seedlings of Quercus serrata by RAPD markers. In: Jain M.S., Gupta P.K. and Newton R.J. (Eds.), Somatic embryogenesis in woody plants, Vol. 4, Kluwer Academic Publishers, Dordrecht, pp. 403-414.

Johansson L., 1983. Effects of activated charcoal in anther cultures. Physiol. Plant. 59: 397-403.

Kim Y.W., Youn Y., Noh E.R., and Kim J.C., 1997. Somatic embryogenesis and plant regeneration from immature embryos of five families of Quercus acutissima. Plant Cell Rep. 16: 869-873.

Lee S.K., 1977. On the asymptotic variances of u-terms in log-linear models of multidimensional contingency tables. J. Am. Statist. Assoc. 72: 412.

Lelu M.A. and Label P., 1994. Changes in the levels of abscisic acid and its glucose ester conjugate during maturation of hybrid larch (Larix $\times$ leptoeuropaea) somatic embryos, in relation to germination and plantlet recovery. Physiol. Plant. 92: 53-60.

Lelu-Walter M.A. and Pâques L.E., 2009. Simplified and improved somatic embryogenesis of hybrid larches (Larix $\times$ eurolepis and Larix $\times$ marschlinsii). Perspectives for breeding. Ann. For. Sci. 66: 104.

Linington I.M., 1991. In vitro propagation of Dipterocarpus intricatus. Plant Cell Tissue Organ Cult. 27: 81-88.

Loureiro J., Pinto G., Lopes T., Dolezel J., and Santos C., 2005. Assessment of ploidy stability of the somatic embryogenesis process in Quercus suber L. using flow cytometry. Planta 221: 815-822.

Manzanera J.A., Astorga R., and Bueno M.A., 1993. Somatic embryo induction and germination in Quercus suber L. Silvae Genet. 42: 90-93.

Mauri P.V. and Manzanera J.A., 2003 Induction, maturation and germination of holm oak (Quercus ilex L.). Plant Cell Tissue Organ Cult. 74: $229-235$.
Mauri P.V. and Manzanera J.A., 2004. Effect of abscisic acid and stratification on somatic embryo maturation and germination of holm oak (Quercus ilex L.). In Vitro Cell. Dev. Biol. Plant 40: 495-498.

Merkle S.A., Parrot W.A., and Flinn B.S., 1995. Morphogenic aspects of somatic embryogenesis. In: Thorpe T.A. (Ed.), In vitro embryogenesis in plants, Kluwer Academic Publishers, Dordrecht, pp. 155-203.

Murashige T. and Skoog F., 1962. A revised medium for rapid growth on bioassays with tobacco tissue culture. Physiol. Plant. 15: 473-497.

Park Y.S., 2002. Implementation of conifer somatic embryogenesis in clonal forestry: technical requirements and deployment considerations. Ann. For. Sci. 59: 651-656.

Pintos B., Manzanera J.A., and Bueno M.A., 2005. Cytological analysis of early microspore divisions leading to gametic embryo formation in Quercus suber L. anther cultures. Acta Physiol. Plant. 27: 703-708.

Pintos B., Manzanera J.A., and Bueno M.A., 2007. Antimitotic agents increase the production of doubled-haploid embryos from cork-oak anther culture. J. Plant Physiol. 164: 1595-1604.

Rao P.S. and Pattabiraman T.N., 1990. Further studies on the mechanism of phenol-sulfuric acid reaction with furaldehyde derivatives. Anal. Biochem. 189: 178-181.

Sommer H.E., Brown C.L., and Kormanik P.P., 1975. Differentiation of plantlets in longleaf pine (Pinus palustris Mill.) tissue culture in vitro. Bot. Gaz. 136: 196-200.

Sutton B., 2002. Commercial delivery of genetic improvement to conifer plantations using somatic embryogenesis. Ann. For. Sci. 59: 657661.

Von Aderkas P., Label P., and Lelu M.A., 2002. Charcoal affects early development and hormonal concentrations of somatic embryos of hybrid larch. Tree Physiol. 22: 431-434.

Weatherhead M.A., Burdon J., and Henshaw G.G., 1978. Some effects of activated charcoal as an additive to plant tissue culture media: Part 1. Z. Pflanzenphysiol. 89: 141-147. 